\title{
The concept of reincarnation as depicted in Indian tradition and culture
}

\author{
Thu Ha Do - Narasingha Charan Pand
}

DOI: 10.18355/XL.2020.13.03.23

\begin{abstract}
Reincarnation is the philosophical or religious concept that the non-physical essence of a living being starts a new life in a different physical form or body after biological death. It is also called rebirth or transmigration, and it can be said that all the religions and cultures in the world have got a central tenet surrounding this concept. India is a country of different traditional spiritual beliefs and religious faiths. People of India generally bind with the spiritual beliefs and sacred thoughts, since time immemorial. Hence, in India, generally, we have the concept of various avatars (incarnations) of Lord Vishnu or Shiva. The traditional scholars of India believe that the avataras are more in number, and they are duly worshipped by the devotees of Lord Vishnu or Shiva in different ages of the Indian tradition and culture. This is really very interesting to know all about the sacred as well as mysterious incarnations of Lord Vishnu as rightly described in the Vedic texts and other spiritual texts, like epics and Puranas. And not only the ancient times but also recent decades have there been many both theologians and scholars worldwide who have developed an interest in reincarnation and many contemporary works mention it on different religions, especially in Buddhism and Jainism. The paper divides into three parts: 1 . The real source of different incarnations (Avartara) in Indian sacred texts; 2 . The incarnation of Lord Vishnu in sacred Sanskrit texts and 3. Reincarnation according to Buddhism.
\end{abstract}

Key words: Reincarnation, Hinduism, Buddhism, Indian culture and tradition

\section{Introduction}

The idea of reincarnation is an ancient idea, originating from a traditional Samsara doctrine of cyclical existence (McClelland, 2010: 24). It was first documented in Indian environment over two thousand years ago. Scholars have been debating whether this is primarily a philosophical or religious concept. Most likely, we can and should consider it as both, since in the Indian intellectual environment, philosophy and religion cannot be easily disentangled, especially when referring to ancient beliefs and philosophical convictions. The concept of reincarnation teaches the continuity of being of a higher living organism. This continuity of being can be manifested either in the same or in a completely different life-form after one's biological death. Thus, most strands of reincarnation teachings refer to this process as the transmigration of a human sould, or spirit. Though there are significant differences and nuances in this doctrine, especially after it had spread to other parts of the ancient world beyond the Indian subcontinent, there are distinct commonly held views and emphases shared by the adherents of this doctrine, whether they are from ancient Greece (Socrates, Plato, Pythagoras, etc.) (Wiley, 2009: 640), mystical strands of Judaism, or more modern religious movements, such as Theosophy, Spiritism, tribal societies of South America and Australia or the New Age in the West (Obeyesekere, 2005: 15).

India is a country of different traditional spiritual beliefs and religious faiths. People of India generally bind with the spiritual beliefs and sacred thoughts, since time immemorial. Hence, in India, generally, we have the concept of various avataras (incarnations) of Lord Vishnu or Shiva. The traditional scholars of India believe that the avataras are more in number, and they are duly worshipped by the devotees of Lord Vishnu or Shiva in different ages of our Indian tradition and culture. This is really very interesting to know all about the sacred as well as mysterious incarnations of Lord Vishnu as rightly described in the Vedic texts and other spiritual texts, like

XLinguae, Volume 13 Issue 3, June 2020, ISSN 1337-8384, ISSN 2453-711X 
epics and Puranas. This paper will only deal with the different incarnations of Lord Vishnu as described in Indian culture and tradition as well as Buddhist thinking about reincarnation.

Ordinarily, we believe and understand that the Sanskrit word avatara means incarnation in English. The incarnation may be of Lord Vishnu or Shiva. But here we will deal about the incarnation of Lord Vishnu as found in Indian tradition and culture. The word Aavatara means to cross over, to attain, to save, with the prefix $a v a-$ down; and so, $a v a+\sqrt{ } t^{a}$ - means to descend in, to appear, to become incarnate) means 'descending' and the term is applied to the act of a Divine or Supernatural Being in assuming the form of man or animal, and continuing to live in that form till the purpose for which that form was assumed or carried out. The incarnation of God on the earth is called avatara. So, avatara is an appearance of any deity on earth, or descent from heaven, and it bears a great importance as a religious concept in the Indian tradition and culture.

\section{Exploring the roots and etymological foundations of the Concept of Reincarnation}

The Latin term of reincarnation - "reincarnatio," means literally to "enter into the flesh again (or: anew)." This idea was directly connected with the concept of the transmigration of the human sould from one physical (biological) body into another one. The sould tended to forget its prior life in this process. However, sophisticated religious rituals and/or meditation could, if done well, help the sould recollect its past lives. The Greek term metempsychosis ( $\mu \varepsilon \tau \varepsilon \mu \psi v ́ \chi \omega \sigma l \varsigma)$ has a different connotation. It can be translated as "changing the state of one's soul" (Harper, 2015). Some scholars (Huffman, 2005: 4) attribute this term to the ancient Greek philosopher, Pythagoras. But the semantic, conceptual idea of transmigration can also be found in Pythagoras and other philosophers of his time and in the subsequent centuries (Oxford Dictionaries, 2016). Another Greek term that is sometimes used, though less frequently, is palingenesis - which, like its Latin counterpart, means "being born again" or "being re-generated" into being.

As the etymology of the concept suggests, reincarnation is the belief that there is something stable and continues in the human being that does not die with his/her physical body. Some cultural traditions hold the conviction that the process of reincarnation applies not only to humans but to other living beings as well (Chapple, 1986: 38-39). Thus, the circle of life is extended to animal and even plant life. The common misconception holds that this term is (and should be) reserved onle to the ancient and myths, religions, and mystical philosophies. This is far from being true, however. Western philosophers such as Karl Sigmund, Kurt Godel, and others have used this term in their philosophical theories.

Though the use of the reincarnation terminology and semantics in the West and around the globe has been well documented by philosophers, philolologists, as well as religious scholars, it is in Indian religions where this concept finds its original birth place and, arguably, the most fertile soil in Jainism, Buddhism as well as Hinduism. Like elsewhere around the world, the concept is identified and described in different terms. The famous $19^{\text {th }}$ century scholar, Monier-Williams (1872: 582), identified several key terms in the Sanskrit texts, namely "Punarjanman" (rebirth, transmigration)," but also "punarāvrtti, punarājāti, punarjī̄ātu, punarbhava, āgatigati, common in Buddhist Pali text." (Monier-Williams, 1872: 582). Behind these ideas is the belief in the endless cycle of Samsara, which can be conceived of as a purification and maturation path of each sancient being towards spiritual maturity and liberation. (Juergensmeyer - Roof, 2011). Even though the term "samsara does not appear in the Vedas," as Keown righly points out, "the notion of cyclic birth and death is an ancient one and dates to around 800 BCE" (Keown, 2003: 248). Thus, the concept of a cyclical rebirth with the aim of one's purification and spirital maturation 
has existed for almost three thousand years. Each human being is inevitably, i.e., by his/her own birth, part of this cycle of life, death, and rebirth. Unlike the Western concept, however, the rebirth is not considered a gift but rather a burden, a curse from which the human being must liberate himself. This tedious "cycle of aimless drifting, wandering or mundane existence," (Roof, 2011: 44) must be broken by living an exemplary life, which can be understood primarily in ethical or, more often, also in mystical, spiritual sense. Rituals, ethical practices and virtues, as well as spiritual meditation (e.g. yoga) are essential parts of this process. The liberation from the cycle of rebirths (reincarnations) is called kaivalya, nirvana, or moksha. (Flood, 2010; Juergensmeyer - Roof, 2011).

\section{Real Source of different Incarnations (Avatara) in India}

The term avatara is relatively late, and an older word for the phenomenon is 'manifestation' (Ávirbhava \& pradurbhava).

\section{Tasya taccataso devaï stutimithaï prakurvataí / \\ Ávirbabhuva bhagavan pitambarodharo harih/}

(Vishnu Purana, I. 20. 14)

The word avatara does not occur in the classical Upanishads, though there are a few references in later Upanishads. It is listed in Panini's Astadhayi (ave trstrorghañ, Astadhyayi, III.3.120) and also occurs in many standard works after the Epic literature. But there are faint glimmerings of the theory of avataras and of these forms even in the earliest Vedic literature (Upadhyaya) (Baladev, 2015: p.170). In the Rgveda it is said that Indra was the grandson of the sage Srngavrsa. This may be interpreted as meaning that Indra was supposed to have descended on the earth in a human form. Niruklta, VIII. 2 explain that "Sayna, the great commentator takes 'napat' to mean 'putra' here.

\section{Yaste Srngavrso napat pranapatkundapayyah/ nyasmindadhra a manah// (Rgveda, VIII.17.13)}

Again, in the Rgveda the sage Vamadeva explains "I was Manu and I was also the Sun".

$$
\begin{aligned}
& \text { ahaï manurabhavaï suryascaham kaksivan rsirasmi viprah/ } \\
& \text { (Rgveda, IV. 26). }
\end{aligned}
$$

This is referred to in the Brhadaranyaka Upanishad and often relied upon in support of the doctrine of the transmigration of souls.

$$
\text { aham brahmasmiti .............pratipede 'ham manurabhavam suryasceti/ }
$$

(Brhadaranyak Upanishad, I.4.10. $C f$.

Sastradrstya tupadeso vamadevavat - Brahma Sutra, I. 1. 30).

It may be capable of that interpretation, but if that is not accepted it will at least tend to support the proposition that the Vedic sage thought that the Sun could be born on the earth as a human being. It clearly indicates that there was an avatara of Sun. Besides, according to the Srimad Bhagavata Purana, the first incarnation of God is Puranas, as it is mentioned in the famous Puranas-sukta of the Rgveda.

$$
\begin{gathered}
\text { jagrhe paurasam rupam bhagavan mahadadibhih/ } \\
\text { sambhutam sodasakalamadau lokasisrksayall } \\
\text { (Bhagavata Purana, I. 3. 1). }
\end{gathered}
$$


Some scholars have definitely observed in the following Rgveda verse (mantra), the germ of the doctrine of the avatara, viz.

\section{pado'sya visva bhutani tripadasyamrtam divi \\ (Rgveda, X.90.3 (purusasukta).}

The great philosopher Prof. S. N. Dasgupta in his History of Indian Philosophy, says that here there is the starting-point of the theism of the Bhagavad Gita, the idea of God as not only immanent but transcendent, a universe which is no illusion, and the doctrine of incarnation/ reincarnation (Dasgupta, 1991: 523ff). Certainly, this hymn is important, and it is quoted in the theistic Svetasvatara Upanishad and in the Gita (Svetasvatara Upanishad, III.12ff; Bhagavad Gita, XIII.13). Hence, the Bhagavata Puranas clearly states that this Puranas form (rupa) is the original source of different avataras, as well as the real base of creation of gods, human beings, animals and other creatures.

\section{etannanavataranam nidhanam bijamavyayam/ yasyansansena srjyante devatiryannaradayah// (Srimad Bhagavata Purana, I. 3.5).}

However, the beginning of the doctrine of avatara and some of the well-known avataras of Vishnu may also be traced to the Vedic literature. In the Vedic idea of Lord Vishnu, as a solar divinity, coming down to the earth from the highest abode, and so in the frequent allusions in the Vedic literature, it is clear that gods assumed different forms in order to accomplish their several exploits. In the Vedic literature, we actually come across of the early indications of the Matsya, Kurma, Varaha, Vamana and other incarnations (Satapatha Brahmana, I.8.1.1-6 (Matsya avatara); VII.5.1.5 (Kurma); XIV. 1.2.11 (Varaha); I.2.5.1ff. (Vamana); and Chandogya Upanishad, III.17.6 (Krishna), etc).

\section{The reincarnation of Lord Vishnu in Hindu sacred texts Real necessity of reincarnation of Lord Vishnu}

The theory of Incarnation brings to mankind a new spiritual message and it presupposes the recognition of Lord Vishnu as a Supreme God, the creator and ruler of the universe, the upholder not only of the cosmic but, also of the moral order of the world. When the enemies endanger the order of the world, the Lord incarnates Himself for the purpose of defending it. It is a comforting belief for the ordinary man to hold that when the affairs of the world are in a mess, Gods come down to the earth to set matters right (Satapatha Brahmana, I.8.1.1-6 (Matsya avatara); VII.5.1.5 (Kurma); XIV. 1.2.11 (Varaha); I.2.5.1ff. (Vamana); and Chandogya Upanishad, III.17.6 (Krishna), etc.), i.e. when the world is in serious trouble, people belief that deliverance will come by the grace of God and they are often justified in their belief by their appearance of godly men who appear with some noble mission and masterly idea suited to the particular time and place when they appear. Another purpose of the Supreme God assuming the worldly form is to educate the mortals (because the people, in general follow the footsteps of the great men).

\section{martyavatarastviha martyasiksanam raksovadhayaiva na kevalaï vibhoh/ (Bhagavata Purana, V.19.5).}

The Supreme Power appears in human form as the guru, the teacher, to lead them beyond the delusion of ignorance, to where there is no difference between the guru 
and the disciple. In addition to these, the manifestation of the Lord is intended only for bestowing the boon of the final beatitude or liberation on the human beings.

As it is rightly said in the Srimad Bhagavata Puranas:

\section{nrnam nihsreyasarthaya vyaktirbhagavato nrpa}

(Srimad Bhagavata Purana, X.26.14; Cf. Bhagavata Purana, III.24.26 \& III.25.1)

\section{Number \& Types of Incarnation of Lord Vishnu in Sanskrit Texts:}

It is very common to find out the various incarnations of Lord Vishnu in different famous Sanskrit texts. In the Mahabharata, the Ramayana and the Puranas, it is frequently stated that Lord Vishnu comes down to the earth often for punishing the wicked, for the protection of good and the establishment of dharma. The Srimad Bhagavata, the most popular Purana, states that the avataras of Vishnu are innumerable, like the rivulets following from an inexhaustible lake (Bhagavata Purana. I. 3. 26. Cf. Harivamsa, I.41.1; Mahabharata, Santiparva, 339.106). In the Mahabharata, the avataras are stated to be ten and they are the same as now generally accepted except that Haïsa which is mentioned instead of Buddha and Krishna is called Satvata (Mahabharata, Santiparva, 339.103-104). Among the Puranas also, several Puranas do not mention Buddha as an avatara. The Matsya Puranas mentions the well-known ten avataras (Matysa Purana, 285.6-7) including Buddha as the 9th avatara (ibid., 47.247) of Lord Vishnu. Besides, the Agni Puranas (Agni Purana, Chapters 2-16), the Padma Puranas (Padma Purana, II.257.40-41) \& the Varaha Puranas enumerate the well-known ten avataras of Vishnu.

matsyai kurmo Varahasca narasinho 'tha Vamanah/

ramo ramasca Krishnasca buddhai kalki ca te dasall

(Varaha Purana, IV.2; cf. Padma Purana, VI.229.90;

Linga Purana, II.48.31-32; Matsya Purana, 285.6-7)

The names of the ten avataras are thus : (1) Matsya-the fish, (2) Kurma-the tortoise, (3) Varaha-the boar, (4) Narasiiha-the man-lion, (5) Vamana- the dwarf, (6) Parasurama (7) Sri Rama, (8) Sri Krishna, (9) Buddha and (10) Kalki. The Bhagavata Puranas makes the number of avataras twenty-two (Srimad Bhagavata Purana, I.3.125) including the minor ones. These are : - (1) Puranas, (2) Varaha, (3) Narada, (4) Nara \& Narayana, (5) Kapila, (6) Dattatreya, (7) Yajña, (8) Rsabha, (9) Prthu, (10) Matsya, (11) Kurma, (12) Dhanvantari, (13) Mohini, (14) Narasiïha, (15) Vamana, (16) Parasurama, (17) Vedavy-asa, (18) Ramacandra, (19) Balarama, (20) Sri Krishna, (21) Buddha and (22) Kalki (yet to come). The Gitagovinda of Sri Jayadeva speaks of ten incarnations (avataras) of Lord Vishnu. Famous Poet Jayadeva takes Balarama as an avatara, instead of Krishna and explain Krishna as the Supreme Lord, the Purusottama in his Gitagovinda.

\section{Vedanuddharate jagannivahate bhugolamudbibhrate........... mlecchanmurcchayate dasakrtikrte krishnaya tubhyah namah// (Gitagovinda, I.1.16)}

The God takes three kinds of incarnations (avataras), such as:

a) Purnavatara (full incarnation): When the God manifests Himself in the form of a human being for the full span of life, this is known as Purnavatara. The examples of this kind are: Sri Rama, Sri Krishna, sage Vedavyasa, etc.

b) Amsavatara (partial incarnation): When the incarnation is only partial, i.e. the activity of such manifestation is limited to a particular time, place or incident, it is called Amsavatara. The most famous and common manifestations of Lord Vishnu 
under this category are in the form of animals of semi-human beings, such as Vamana, Varaha, Narasiïha, Kurma, Matsya, etc.

c) Avesavatara: Avesa means over-shadowing. The example of this kind is Parasurama avatara (Vide, Mahabharata, II.49; III.98; 116-117, etc; Matsya Purana, Ch. 47; Vishnu Purana, IV.7; IV.11; Srimad Bhagavata Purana, I. 3. 20; II.7.22). When Sri Rama had married Sita, he had to fight Parasurama in a violent duel. This incident subsebquently served as the origin of Sri Rama's exaltation and Parasurama's denigration. While Parasurama became only a sage, Sri Rama received the sould of Parasurama. This could happen because of Vishnu who overshadowed (Avesa overshadowing) the soul of Parasurama.

\section{Incarnation (Avatara-vada) \& the theory of Evolution:}

The avataras give us the keys which will make us unlock the mysteries of nature. They represent the different stages of evolution in the different departments of nature. Even if we take into consideration the ten avataras (of Lord Vishnu) as they stand, the different stages of evolution are there. The circumstances which necessitated these avataras and the mighty deeds accomplished by Vishnu on these occasions are most graphically and exhaustively described. Attempts have been made to rationalize the different forms assumed by Vishnu in different incarnations. In the beginning of the creation there were waters everywhere, and, to suit this condition of the world, the first incarnation of Vishnu was, appropriately enough, in the form of a fish-the animal to be found in water and therefore in His second incarnation, Lord Vishnu appeared as a tortoise, which can easily move both in water and land. The later stages of evolution are of animal life in the forests. After this, the boar (Varaha) incarnation has appeared. The Boar lives on land alone. Next, we have the transition between the animal and the human worlds in the man-lion (Narasimha) incarnation. The development is not completely fulfilled when we come to the dwarf (Vamana) incarnation. The first stage of man is that of the brutish, violent, uncivilized Rama with axe (Parasurama), who devastates the rest of humanity; later we get the Divine Spiritual Sri Rama, who consecrates family life and affections, and Sri Krishna, who exhorts us to enter into the warfare of the world; and after him Buddha, who, full of compassion for all living beings, works for the redemption of mankind. Last of all we have the incarnation yet to come, the Kalki, who will fight against evil and injustice with the sword in hand.

It can be said that, through this part of the paper, the scholars may get some general idea of the various incarnations of Lord Vishnu as described in the Epics, Puranas, and other traditional texts of Sanskrit. Although the number of incarnations may be more or less, but we should try to critically understand and study the real and sacred nature of various incarnations in different ages as found in the Sanskrit texts.

\section{Reincarnation according to Buddhism}

The issue of reincarnation in Buddhist teachings often causes a lot of debate, especially since Buddhism was introduced into the Western world ... Is reincarnation a particular Buddhist concept? Is it a very common belief in India that the Buddha "incorporated" into his teachings? So should one believe in reincarnation or should it be considered a doctrine that needs revision? Is reincarnation a true continuation of many different biological lifetimes or rather just different mental forms that can (or may not) happen to each individual person right in this present life? One of the distinct values of Buddhism is the idea of impermanence. As Damien Keown rightly emphasizes, "A fundamental tenet of Buddhism is that all formations (samskara) things that come into being dependent on causes and conditions - are impermanent" (Keown, 2003: 32).

There are divergent interpretations of this, however. Concrete texts can be presented that seem to document Guatama Buddha's belief in the existence of a world after this visible, temporal world. That is, according to some texts, Buddha directly believed in 
the afterlife and the possibility of reincarnation of the human souls. Harvey (2012: 112), for example, cites a text from Majjhima Nikaya (i. 402; Apannaka Sutta) that says the following: "since there actually is another world (any world other than the present human one, i.e. different rebirth realms), one who holds the view 'there is no other world' has a wrong view..." Ajahn Sucitto (2010:37-38) concurs and provides more textual evidence of the same. Of course, there were other schools of thought before Buddha, some of which continued to exert its influence long after his death. The materialistic school of Charvaka, for example, promoted the opinion that death is the final end of all human life. As we live in a material universe, there is no afterlife. (Billingont, 2002) Human body, mind and memories are completely annihilated. No vestiges of personality, or personal stories are left to be reincarnated in a process of transmigration of souls.

Buddha was aware of the teaching of such schools and rejected them. (Keown, 2013: 162; Neufeldt, 1986) Instead, he insisted on a karmic influence on the cycle of life and rebirths. His concern was not religious, nor mystical, but rather ethical. Buddha was convinced that if humans live in a random, purposeless world of material causes and effects, they could not develop a sense of responsibility. Instead, they would necessarily degenerate into lawlessness and hedonism. (McClelland, 2010) Only if a karmic cycle can be established, there will be enough impulse and motivation for humans to act responsibly. (Keown, 2013: 225).

Reincarnation is the basic teaching of Buddhism. The bodhisattvas' happiness to flourish on the road to Buddhahood is based on the teaching of reincarnation.

The doctrine of the Buddhist reincarnation is quite different from the concept of the reincarnation of the soul in some religions. Because Buddhism does not recognize that there is an eternal soul to be reborn from one life to another. Only karma results in reincarnation, that is, from the past karma leads to the present and by the present karma merging with the past karma creates future reincarnation. The present person is the biological child of the past and it will give birth to the future person. Thus, there is a series of processes connecting the past life to the present and the future, from which one questions what is the source of life.

There are religions that advocate that human life comes from a metaphysical omnipotent being called God. For instance, Islamic scriptures reject any idea of reincarnation of human beings or God (McClelland, 2010: 122-123). It teaches a linear concept of life, wherein a human being has only one life and upon death is judged by God, then rewarded in heaven or punished in hell (Geisler - Saleeb, 2002). Islam teaches final resurrection and Judgement Day but there is no prospect of reincarnation of a human being into a different body or being (McClelland, 2010: 122-123).

There is also a belief that the soul of man is born of God and the parents only help to add the outer shell to the soul. According to science, humans are born from a combination of the father's sperm and the mother's oocyte, but science cannot clearly explain the development of the spirit more important than the body. According to Buddhism, we are born from a template that contains all our actions from the past, and our parents give us material bases. In particular, the intangible power of the past karma generates the spirit and spirit combined with the vigor of the parents' body, forming the three factors that make up human life: consciousness, vigor and pregnant.

In the Mahatanhasankhaya Sutta, No. 38, of Majjhima Nikaya, it is stated that in the intercourse of the parents, if the mother's conception does not occur and there are no reincarnated beings, the germ cannot be planted. If at the time of the mother's conception, there are no reincarnating beings, then the germ of life cannot be planted. If the mother's conception and the birth of a reincarnate being are also present during sexual intercourse, if all three elements, namely sperm, oocyte, and consciousness (Vijnàna) are met, the germ is planted. 
Some religions, or the doctrines that death is finished, when the human body is destroyed, their life ends, there is no successive reincarnation, so doing the sins has no consequences at all. On the contrary, according to Buddhism, the continuous life of man flows forever in the six paths of Samsāra by the continuous accumulation of ignorance and craving. Trainor (2004) analyzes the relationship of Saṃsāra with karma in the Buddhist doctrine. "Buddhist doctrine holds," Trainor observes "that until they realize nirvana, beings are bound to undergo rebirth and redeath due to their having acted out of ignorance and desire, thereby producing the seeds of karma" (Trainor, 2004: 62-63) Samsara is identified here with dukkha, which, together with avidya (ignorance) afflict the human life. The karmic cycle is provided here as a healing and entlightening space where illumination (englightenment) can take place.

Only when ignorance and craving are completely cut off, the reincarnation in the cycle of Samsāra will cease and that is one of the preeminent effects of the Buddhas and the Arahats.

Therefore, in many suttas, the Buddha often taught that those who do evil, after death will be reborn in misery, beings who do good, will be reborn in a peaceful scene. And the Buddha showed great compassion, so he often sought predestined people for salvation, because he saw that they were creating sin that would adversely affect their future lives (Wilfred, 2011: 74-75). In fact, people think superficially that "death is the end", they often overlook the good and easily do evil, leading to the consequences of suffering for themselves, their families and society.

While the disciple practices Dharma, having faith in karma and reincarnation will reap many practical benefits for himself, his family and the social community. Indeed, first of all, correctly understanding the Buddha's teaching that our present life is good, or suffering stemming from the acts of artifact from past lives, we easily accept the bad situations that we are suffering, meaning that we are happy to be responsible for the debt we have borrowed from our past life, without resentment to those around us. And further, understanding the consequences of past actions leading to the present life, we are also at ease against the disparity commonly known as social injustice as well as understand the causes of differences in intelligence, health, material and mental life... of us and others.

Buddhists deeply believe in the fair justice law of karma, that is, the thoughts, words and deeds created in the past life are the nucleus that make up our body and our present life. With such awareness, Buddhists certainly do not evade the results of karma in samsaric flow, helping them to diligently cultivate their thoughts, words and deeds well according to the Buddha's teaching, inevitably will make their present life and future peaceful, happy and liberated.

Even the Buddha also said Devadatta - his brother always caused trouble with him from past lives to the present life (Davids, 2010). We see that Buddha also has this karma and that He can neutralize it, so we learn that Buddha must know how to resolve. Therefore, the Buddha said that Bodhisattvas do great things because they know how to cultivate good karma from the past. In the past, Bodhisattvas once devoted themselves to saving lives, so today, the people wholeheartedly devote to Bodhisattvas, which is normal. Typically, 500 Arahats in their previous lives were rescued by the Buddha from the murder of pirates, so whenever they were reborn, they met Buddha and followed Buddha soon, attaining Arahats quickly. Precisely because the intimate relationship of LIFE-DEATH-REINCARNATION thus continues in a continuous stream on the continuum of human life, Samantabhadra Bodhisattva has reminded Buddhists to practice, how to be reborn in species all know their previous life, then they never fail (ten great vows in Avatamasaka Sutra).

\section{Conclusion}

Reincarnation has been a complex and sometimes controversial concept. Yet, it must not be ignored as it remains at the core of most of ancient and even contemporary 
thinking in India. We have been able to show that this concept, though with sifted, sometimes contradictory meanings, has been adopted and adapted by other parts of the world. It has come to govern the minds of faithful Hindus but also other religions, and religious movements. It cannot be circumscribed to ancient history; to the contrary, it remains influential even in modern, Western religious movements. We do not need to establish firmly to what extent the idea of reincarnation can be ascribed a truth value from an ontological perspective. Not only is it impossible, epistemologically speaking, but it is not even necessary. Suffice to say that this concept influences ethical and social imaginaries of countless millions in India and beyond. As on of the world religions' most common and foundational idea, the concept of reincarnation exerts its influence and shapes the moral behavior of individuals and social norms of human societies. And nowadays, it seems that the question about reincarnation is still stirring the human mind both as beautiful hope and academic curiosity! However, from the above discussions with textual evidences and explanations, it may be safely concluded that the tendency of showing oneness to many forms, i.e. henotheism to polytheism and finally go back to the oneness indicating the Vedic theory of monotheism, e.g. 'ekam sad vipra bahudha vadanti....' Secondly, it is also clear that an avatara or incarnation is a descent of God into man and not an ascent of man into God.

eka murtirstrayo deva brahmavishnumehesvarash/

(Devi Bhagavata Purana, I. 8. 4)

Although we accept a number of avataras of either Lord Vishnu or Lord Shiva, but in reality, both are conceived as one and these incarnations are treated as the essence or part of one God or Absolute, appear in the world for the protection of dharma as well as for the welfare of beings in time.

\section{Bibliographic references}

BALADEV, U. 2015. Purana Vimarsa, Ch. V, Chowkhamba publisher, Varanasi, 3rd Edition.

BILLINGTON, R. 2002. Understanding Eastern Philosophy. Routledge. ISBN 978-1134-79348-8.

BRADEN, C.S. 1941. Man's Quest for Salvation: An Historical and Comparative Study of the Idea of Salvation in the World's Great Living Religions. Chicago \& New York: Willett, Clark \& Company.

CHAPPLE, C.K. 1986. Karma and creativity. New York: State University of New York Press, ISBN 0-88706-251-2.

DASGUPTA, S. N. 1991. A History of Indian Philosophy, Part II. Delhi: Motilal Banarsidass Publ.

DALAI LAMA. 2002. How to Practice: The Way to a Meaningful Life. New York: Atria Books.

DAVIDS, T.W. 2010. Buddhist Birth-Stories and Jataka Tales. Translated from V. Fausboll's Ed. Berlin: Truebner. ISBN 9781176233218.

DUNDAS, P. 2003. The Jains. London: Routledge. ISBN 978-0415266055.

ESPOSITO, J.L. 2004. The Oxford Dictionary of Islam. Oxford University Press. ISBN 978-0-19-975726-8.

FLOOD, G.D. 2010. Brill's Encyclopedia of Hinduism. Jacobsen, K. (ed.). Volume II. Leyden: Brill, pp. 881-884. ISBN 978-90-04-17893-9.

GEISLER, N.L. - SALEEB, A. 2002. Answering Islam: The Crescent in Light of the Cross. New York: Baker Academic. ISBN 978-0-8010-6430-2.

GRAVES, W. Jr. 2011. In Pursuit of Wholeness: Experiencing God's Salvation for the Total Person. Shippensburg, PA: Destiny Image. 
HARVEY, P. 2012. An Introduction to Buddhism: Teachings. History and Practices. Cambridge: Cambridge University Press. ISBN 978-0-521-85942-4.

HUFFMAN, C. 2005. Pythagoras: The Fate of the Soul-Metempsychosis. In: Stanford Encyclopedia of Philosophy. Stanford: Stanford University Press. First published 2005; substantive revision Wed Oct 17, 2018. Available online: https://plato.stanford.edu/entries/pythagoras

JAINI, P. - DONIGER, W. (eds.) 1980. Karma and Rebirth in Classical Indian Traditions. Berkeley: University of California Press.

JUERGENSMEYER, M. - ROOF, W.C. 2011. Encyclopedia of Global Religion. New York: SAGE Publications. ISBN 978-1-4522-6656-5. pp. 271-272.

KEOWN, D. 2003. Oxford Dictionary of Buddhism. Oxford: Oxford University Press. KEOWN, D. 2013. Buddhism: A Very Short Introduction. Oxford University Press. ISBN 978-0-19-966383-5.

MCCLELLAND, N.C. 2010. Encyclopedia of Reincarnation and Karma. London: McFarland. ISBN 978-0-7864-5675-8.

MONIER-WILLIAMS, M. 1872. A Sanskrit-English Dictionary. Oxford: Oxford University Press.

NEUFELDT, R.W. 1986. Karma and Rebirth: Post Classical Developments. New York: State University of New York Press. ISBN 978-0-87395-990-2.

NORMAN, E.T. 1988. Liberation for Life: A Hindu Liberation Philosophy. In: Missiology: An International Review, vol. 16, n. 2, pp. 149-160.

OBEYESEKERE, G. 2005. Karma and Rebirth: A Cross Cultural Study. Delhi: Motilal Banarsidass. ISBN 978-8120826090.

OBEYESEKERE, G. 2002. Imagining Karma: Ethical Transformation in Amerindian, Buddhist, and Greek Rebirth. Berkley: University of California Press. ISBN 0-52023220-8.

OXFORD DICTIONARIES. 2016. “Transmigration”. Oxford - New York: Oxford University Press.

JAINI, P. S. 1998. The Jaina Path of Purification. Delhi: Motilal Banarsidass Press. ISBN 81- 208-1578-5.

TRAINOR, K. 2004, Buddhism: The Illustrated Guide. Oxford: Oxford University Press. ISBN 978-0-19-517398-7.

SMITH, J.I. - HADDAD, Y.Y. 2002. The Islamic Understanding of Death and Resurrection. Oxford: Oxford University Press. ISBN 978-0-19-028880-8.

SUCITTO, A. 2010. Turning the Wheel of Truth: Commentary on the Buddha's First Teaching. Delhi: Shambhala.

WILEY, K.L. 2009. The A to Z of Jainism. London: Scarecrow. ISBN 978-0-81086337-8.

WILFRED, G. Jr. 2011. In Pursuit of Wholeness: Experiencing God's Salvation for the Total Person. Shippensburg, PA: Destiny Image.

\section{Sacred texts used to study in the paper}

Agni Purāna, translated into English by J.L. Shastri (1998). Delhi: Motilal Banarsidass, 4 Volumes. Reprint edition.

Bhāgavata Purāna: with English translation (1995). Gorakhpur: Gita Press edition, 3 Volumes, fourth edition.

Garuḍa Purāna: edited by Khemaraja Sri Krishna Dass (1983). Delhi, India: Nag Publishers.

Kūrma Purāna: edited by Naga Saran Singh (1983), Delhi: Nag Publishers.

Kūrma Purāna, translated into Eng. by G.V. Tagare (1997-98). Delhi: Motilal Banarsidass, 02 Vols, Reprint Edition.

Manusmriti: edited with the comm. of Kulluka Bhatta, by J.L. Shastri (1990). Delhi: Motilal Banarsidass, Reprint Edition. 
Rigveda Samhitā: edited by S. Damodar Satavalekara (1985). Pardi, Maharashtra, India: Svadhyaya Mndala, 4 Volumes.

Shiva Purāna: edited by Ramtej Pandey (1986). Varanasi: ChowkhambaVidyabhavana.

Vāmana Purāna: edited with English translated by Ananda Swarup Gupta (1968). Varanasi: All India, Kashiraj Trust.

Varāha Purāna: ed. by A.S. Gupta, translated into English by A. Bhattacharya (1981). Ramnagar, Varanasi: All India Kashiraj Trust.

Vishnu Purāna: with Hindi translation (1961). Gorakhpur, U.P., India: Gita Press Gorakhpur edition.

Yoga Sūtra: with the commentary of Vyāsa, sub-commented by Hariharananda Aranya, edited by Ram Shankar Bhattacharya (1991). Delhi: Motilal Banarsidass, Reprint Edition.

Words: 5839

Characters: 36974 (20,5 standard pages)

Assoc. Prof. Dr. Ha Thu Do

Head, Department of Indian Studies

Faculty of Oriental Studies

VNU, University of Social Sciences and Humanities, Hanoi

336 Nguyen Trai Str., Thanh Xuan District, Hanoi

Vietnam

dothuha2000@gmail.com

Prof. Dr. Narasingha Charan Pand

ICCR Chair Visiting Professor of Sanskrit, Sanskrit Studies Centre,

Faculty of Archeology

Silpakorn University, Bangkok

Thailand

ncpanda@gmail.com 